\title{
Glyphosate Influence on the Physiological Parameters of Conyza bonariensis BIOTYPES ${ }^{1}$
}

\author{
Influência de Glyphosate em Parâmetros Fisiológicos de Biótipos de Conyza bonariensis
}

\author{
VARGAS, L. ${ }^{2}$, SILVA, D.R.O. ${ }^{3}$, AGOSTINETTO, D. ${ }^{3}$, MATALLO, M.B. ${ }^{4}$, SANTOS, F.M. ${ }^{5}$, ALMEIDA, \\ S.D.B. ${ }^{4}$, CHAVARRIA, G. ${ }^{2}$, and SILVA, D.F.P. ${ }^{5}$
}

\begin{abstract}
The objective of this study was to determine changes in gas exchange and inhibition of EPSPs, based on the accumulation of shikimic acid in horseweed biotypes resistant and sensitive to glyphosate. Two experiments were conducted in a factorial model. The first one evaluated horseweed biotypes (one resistant and one susceptible to glyphosate), and herbicide rates $\left(0\right.$ and $1,080 \mathrm{~g}$ a.e. $\left.\mathrm{ha}^{1}\right)$ applied on the weed. In the second experiment, the horseweed biotypes (susceptible and resistant to glyphosate) were evaluated in five periods as following: $0,3,7,10$, and 14 days after herbicide application (DAH). The photosynthetic rate, transpiration, carboxylation efficiency, and water efficiency were determined using an infrared gas analyzer (IRGA), and shikimic acid concentration by HPLC. The application of glyphosate damaged the photosynthetic parameters of the susceptible biotype, causing complete inhibition of the photosynthetic rate, transpiration rate, carboxylation efficiency and water use efficiency, starting from the $7 \mathrm{DAH}$. On the other hand, total inhibition of the photosynthetic parameters was not observed for the resistant biotype. Shikimic acid accumulation occurred in both biotypes after glyphosate application but the susceptible biotype had the highest concentrations, indicating greater sensitivity of the enzyme EPSPs. The accumulation of shikimic acid in the resistant biotype indicates that the mechanism of resistance is not related to the total insensitivity of the enzyme EPSPs to glyphosate and/or that other resistance mechanisms may be involved.
\end{abstract}

Keywords: hairy fleabane, resistance, photosynthesis, EPSPs, shikimic acid.

RESUMO - Objetivou-se neste trabalho determinar alterações na fotossintese e na inibição da EPSPs, com base no acúmulo de ácido chiquímico, em biótipos de buva resistente e suscetivel ao glyphosate. Foram realizados dois experimentos, conduzidos em esquema bifatorial. No primeiro, avaliaram-se biótipos de buva (um resistente e outro suscetivel ao glyphosate) e doses do herbicida (O e $1.080 \mathrm{~g}$ e.a. $\mathrm{ha}^{-1}$ ) aplicadas sobre a planta daninha. No segundo experimento, os biótipos de buva (resistente e suscetivel ao glyphosate) foram avaliados em cinco épocas: 0, 3, 7, 10 e 14 dias após a aplicação do herbicida (DAH). Foram efetuadas determinações da taxa fotossintética, transpiração, eficiência da carboxilação e uso eficiente da água, empregando analisador de gases no infravermelho (IRGA), e a concentração de ácido chiquímico, determinada por HPLC. A aplicação do glyphosate afetou negativamente os parâmetros fotossintéticos do biótipo suscetivel, causando total inibição da taxa fotossintética, da taxa transpiratória, da eficiência da carboxilação e da eficiência do uso da água, a partir dos 7 DAH. Já para o biótipo resistente, não se observou total inibição dos parâmetros fotossintéticos. Em ambos os biótipos ocorreu acúmulo de ácido chiquímico após aplicação de glyphosate; contudo, o biótipo suscetivel apresentou as maiores concentrações, indicando maior sensibilidade da enzima EPSPs. O acúmulo de ácido chiquímico no biótipo resistente indica que o mecanismo de resistência não está relacionado somente com a insensibilidade da EPSPs ao glyphosate e/ ou que outros mecanismos de resistência podem estar envolvidos.

Palavras-chave: buva, resistência, fotossíntese, EPSPs, ácido chiquímico.

Recebido para publicação em 27.7.2013 e aprovado em 16.11.2013.

2 Embrapa Trigo, Passo Fundo-RS, Brasil, <leandro.vargas@embrapa.br>; ${ }^{3}$ Universidade Federal de Pelotas, Capão do Leão-RS, Brasil; ${ }^{4}$ Instituto Biológico, Campinas-SP, Brasil; ${ }^{5}$ Instituto Federal do Rio Grande do Sul, Sertão-RS, Brasil; ${ }^{5}$ Instituto Biológico, Campinas-SP, Brasil; ${ }^{6}$ Universidade de Passo Fundo, Passo Fundo-RS, Brasil. 


\section{INTRODUCTION}

The introduction of the Roundup Ready (RR) soybeans in Brazil provoked changes in the handling of weeds, once only one herbicide was necessary for the control of the ample variety of species. Consequently, this technology led to impacts on the community of weeds, especially by the evolution of glyphosate resistance due to the repetitive use of this herbicide.

In Brazil, five species resistant to glyphosate were reported, Lolium multiflorum being the first case described in Rio Grande do Sul in 2003. Subsequently, other species were selected with resistance to the herbicide, being Conyza bonariensis, C. canadensis, C. sumatrensis and Digitaria insularis (Heap, 2012).

Glyphosate is one of the most commonly used herbicides in the world to control weeds, and it stands out for being a systemic, non-selective control product of magnoliopsida and liliopsida species, whether annual or perennial. This herbicide inhibits 5enolpyruvilshikimate-3-phosphate synthase (EPSPs), a key enzyme in the shikimate pathway (Herrmann, 1995a). The connection of glyphosate to EPSPs results in rapid accumulation of shikimate-3-phosphate, which is hydrolyzed in the plant for shikimic acid by vacuolar phosphorylases (HollanderCzytko \& Amrhein, 1983). Shikimic acid is an important intermediate in the biosynthesis of aromatic amino acids phenylalanine, tyrosine and tryptophan, among other secondary metabolites such as flavonoids, anthocyanins, carotenoids, auxins, lignans, alkaloids and phytoalexins (Herrmann, 1995 a, b).

For detection of weed resistance, several methods have been developed, some have shown to be more advantageous due to less use of resources, and others more sophisticated, due to the need for manpower and specialized equipment. In the specific case of glyphosate resistance, the accumulation of shikimic acid has been studied to assess the sensitivity of the enzyme EPSPs to the herbicide using chromatography and spectrophotometry (Zelaya et al., 2011). However, the extraction of shikimic acid directly from the plant tissue requires a long time and large amounts of reagents, so the methods of extraction in water, using solvent extraction assisted by microwave, have been presented as a simple form of shikimic acid extraction (Matallo et al. 2009). Another way to evaluate the resistance to glyphosate is the inhibitory effect of plant photosynthesis (Duke et al., 2003). The photosynthetic rate, transpiration, carboxylation efficiency and water use efficiency are parameters that may indicate the effect of glyphosate on the plant.

Given the above, the aim of this study was to determine changes in photosynthesis and inhibition of EPSPs, based on the accumulation of shikimic acid in horseweed biotypes resistant and susceptible to glyphosate.

\section{MATERIAL AND METHODS}

The experiments were conducted in a greenhouse, the seeds of resistant and susceptible horseweed were germinated in plastic pots with a capacity of $500 \mathrm{~mL}$, containing Garden Plus Turfa Fértil ${ }^{\mathbb{B}}$ substrate, a compost of peat and calcitic limestone, and supplemented with minerals $(\mathrm{N}=$ $0.02 \% ; \mathrm{P}_{2} \mathrm{O}_{5}=0.08 \%$ and $\mathrm{K}_{2} \mathrm{O}=0.04 \%$ ). The technical characteristics of the substrate were: $\mathrm{pH}=5.8 \pm 0.5$; electrical conductivity $=$ $1.5 \pm 0.3$; maximum moisture $($ mass $/$ mass $)=$ $55.0 \%$; density on a dry basis $=290 \mathrm{~kg} \mathrm{~m}^{3}$; and water holding capacity (CRA) $=60 \%$ in mass. After emergence, the plants were thinned, leaving three plants per pot. The irrigation of the experiments was carried out directly in the trays containing the pots, with holes in the bottom, where the water was absorbed by capillarity.

Upon reaching 10 to 12 leaves, the plants were treated with glyphosate. The herbicide application was made with a $\mathrm{CO}_{2}$ high pressure backpack sprayer, equipped with flat fan tips TeeJet XR 115.02, spaced $0.5 \mathrm{~m}$, spray volume of $120 \mathrm{~L} \mathrm{ha}^{-1}$ and working pressure of $23 \mathrm{lb} \mathrm{pol}^{-2}$. At the time of application, the temperature was $22{ }^{\circ} \mathrm{C}$ and relative humidity was $65 \%$.

The first experiment was conducted in a completely randomized design in a $2 \times 2$ factorial with four replications. In factor A were allocated doses of glyphosate $(0$ and $1,080 \mathrm{~g} \mathrm{e.a.} \mathrm{ha-1)}$, and in factor B, the 
horseweed biotypes (resistant and susceptible). At 14 days after the herbicide treatments (DAH), the dry matter (DM) of the plants dried in an oven with forced air circulation, maintained at the temperature of $60{ }^{\circ} \mathrm{C}$ for 48 hours, was evaluated.

The second experiment was conducted in a completely randomized design in a $2 \times 5$ factorial with four replications. In factor A were allocated the horseweed biotypes (resistant and susceptible), and in factor $B$, the times of application of glyphosate $(0,3,7,10$ and $14 \mathrm{DAH})$. In this essay, were evaluated the photosynthetic rate $(\mathrm{A})$, transpiration $(\mathrm{T})$, carboxylation efficiency (CE), water use efficiency (WUE) and the concentrations of shikimic acid in the leaves. In both experiments, the treatments were arranged in randomized blocks with four replications.

Photosynthetic rate, transpiration, carboxylation efficiency and water use efficiency were measured with the use of an infrared gas analyzer (IRGA) model LI-6400XT, equipped with an artificial light source system and automatic $\mathrm{CO}_{2}$ injection. During the reading, the photons flux density was set to $1.500 \mu \mathrm{mol} \mathrm{m}^{-2} \mathrm{~s}^{-1}$, injection of $\mathrm{CO}_{2}$ into the chamber of $400 \mu \mathrm{mol} \mathrm{mol}^{-1}$, leaf temperature of $20{ }^{\circ} \mathrm{C}$ and air flow of $500 \mu \mathrm{mol} \mathrm{s}^{-1}$. Subsequently, the carboxylation efficiency (CE) and water use efficiency (WUE) were calculated by the reason of the variables A/substomatal $\mathrm{CO}_{2}$ concentration (Ci) and $\mathrm{A} / \mathrm{T}$, respectively. The evaluations were made between the $1 \mathrm{pm}$ and $3 \mathrm{pm}$, using the leaf with further development of all three plants in each pot.

For analysis of shikimic acid, the plants were cut close to the ground surface, separating the leafs and subsequently drying them in an oven at a temperature of $60^{\circ} \mathrm{C}$ for 16 hours. After the samples reached constant weight, they were ground in a mill at $2500 \mathrm{rpm}$ and stored under refrigeration $\left(-10{ }^{\circ} \mathrm{C}\right)$ until the time of extraction and determination of shikimic acid.

For the extraction of shikimic acid, aliquots of $100 \mathrm{mg}$ of DM were divided into falcon tubes $(50 \mathrm{~mL})$, adding $10 \mathrm{~mL}$ acidified ultrapure water to $\mathrm{pH} 2.0$ with $85 \%$ phosphoric acid. After manual homogenization, the tubes were individually placed in the center of the microwave oven, selecting the power of $100 \mathrm{~W}$ for nine seconds. At the end of extraction, the temperature of the suspension was $70{ }^{\circ} \mathrm{C}$. After reaching room temperature, the suspension was filtered through a No. 1 Whatman paper filter and a $0.45 \mu \mathrm{m}$ membrane filter (Millex-GV, Millipore) for chromatographic analysis.

The shikimic acid concentration was determined by HPLC (Shimadzu LC 2010) equipped with VP 6.0 software, autoinjector of samples and chain diode detector (DAD) with measurements at a wavelength of $212 \mathrm{~nm}$, using chromatographic column Phenomenex Gemini C18 $110 \mathrm{~A}^{\circ}(250 \mathrm{~mm} \times 4 \mathrm{~mm}$; particle size $5 \mu \mathrm{m}$ ) and injection volume of $20 \mu \mathrm{L}$. The isocratic system was 95:5 (acidified ultrapure water to $\mathrm{pH} 3.5$ with phosphoric acid: methanol) and $0.80 \mathrm{~mL} \mathrm{~min}^{-1}$ flow. The run time was 10 minutes, with shikimic acid retention at 5.6 minutes.

All data obtained were checked for homogeneity of variance and then subjected to ANOVA, and treatment means compared by least significant difference (DMS) (p 0.05).

\section{RESULTS AND DISCUSSION}

It was possible to observe an interaction between horseweed biotypes and glyphosate doses for $\mathrm{DM}$ at $14 \mathrm{DAH}$, indicating that herbicide application at a dose of $1,080 \mathrm{~g} \mathrm{ha}^{-1}$ and e.a. stalled the growth of the susceptible biotype by $57 \%$, while for the resistant biotype DM was not affected (Table 1). A similar result was observed by Mueller et al. (2003), when resistant biotypes of Conyza canadensis showed stoppage of increment of DM by about $40 \%$ after

Table 1 - Dry matter (mg per plant) of horseweed biotypes evaluated at 14 days after glyphosate application (1.080 g e.a. ha-1)

\begin{tabular}{|c|c|c|}
\hline $\begin{array}{c}\text { Dose } \\
\left(\mathrm{g} \mathrm{ha}^{-1} \text { of e.a. }\right)\end{array}$ & $\begin{array}{c}\text { Resistant } \\
\text { biotype }\end{array}$ & $\begin{array}{c}\text { Susceptible } \\
\text { biotype }\end{array}$ \\
\hline \multicolumn{3}{|c|}{ Dry matter (mg per plant) } \\
\hline 0 & $624.25 \mathrm{aA}^{\underline{1}}$ & $692.75 \mathrm{aA}$ \\
\hline 1080 & $473.87 \mathrm{aA}$ & $298.62 \mathrm{bB}$ \\
\hline
\end{tabular}

${ }^{1 /}$ Means followed by the same letter, lowercase in the columns and uppercase in the lines, do not differ by LSD test $(p>0,05)$. 
application of $840 \mathrm{~g} \mathrm{ha}^{-1}$ and glyphosate e.a., while the susceptible biotypes showed a drop of more than $80 \%$ at $17 \mathrm{DAH}$.

The production of DM in the control was similar between resistant and susceptible biotypes (Table 1), while herbicide application paralyzed the increment of DM production of the susceptible biotype compared to the resistant biotype. Although the glyphosateresistant biotype has not reduced its growth, the plants showed little injury, mainly chlorosis in growth points. These symptoms were observed three days after application in both biotypes; however, susceptible plants did not recover their normal state and at $7 \mathrm{DAH}$, they already presented irreversible symptoms such as shriveling, and some necrotic spots on the ends of the leaves. Now resistant plants showed only a mild chlorosis in the young leaves at $14 \mathrm{DAH}$. Among the possible causes for the appearance of symptoms of glyphosate phytotoxicity in resistant plants, the presence of aminomethylphosphonic acid (AMPA) can be one of them.

AMPA is the product of glyphosate degradation by the glyphosate oxidoreductase enzyme (GOX) by plants, and can be phytotoxic even in plants that possess the EPSPs enzyme insensitive to glyphosate (Nandula et al., 2007). Another possible cause is the direct effect of glyphosate on the amount of chlorophyll or immobilization of $\mathrm{Mg}$ and $\mathrm{Mn}$, which are essential to the functionality and production of chlorophyll (Zobiole et al., 2010b).

In the second experiment, the factors horseweed biotype and times of application of glyphosate showed a significant interaction; the unfolding of this interaction showed that the variables photosynthetic rate (A), transpiration $(\mathrm{T})$, carboxylation efficiency $(\mathrm{CE})$, water use efficiency (WUE) and accumulation of shikimic acid were affected (Figures 1 and 2). For both horseweed biotypes there were reductions in photosynthetic rate after herbicide application, due to its effect on physiological mechanisms, such as photosynthesis, rubisco activity and proteins related to photosynthesis (Sergiev et al., 2006), although the binding of glyphosate occurs specifically on a metabolic target on the plant - in this case, the EPSPs enzyme. For the susceptible biotype, assessments subsequent to $7 \mathrm{DAH}$ were not performed due to phytotoxic damage caused by herbicides.

The resistant biotype always showed a significantly higher photosynthetic rate than the susceptible biotype under the effect of the herbicide until $7 \mathrm{DAH}$, regardless of the time of evaluation. When compared with the control (0 DAH) significant reductions were observed at $7 \mathrm{DAH}$ both in the susceptible and resistant biotypes, extending until $14 \mathrm{DAH}$ in the latter (Figure 1). Inhibition of EPSPs deregulates the carbon flow in the shikimate pathway, with a consequent reduction in metabolites occurring during the dark phase of photosynthesis, and this change in the carbon metabolism in the leaves inhibits photosynthesis (Geiger et al. 1999).

For the resistant biotype, glyphosate did not cause complete inhibition of $\mathrm{CO}_{2}$ assimilation and, possibly, photosynthesis reestablished itself over time (Figure 1). Similar results are observed in glyphosateresistant soybeans after herbicide application, in which $\mathrm{CO}_{2}$ assimilation rate, transpiration rate, carboxylation efficiency and water use efficiency were affected by the application of the product (Zobiole et al., 2010a).

The response of the resistant biotype at $3 \mathrm{DAH}$ indicated an increase in transpiration rate $(\mathrm{T})$, probably due to increased metabolic activity, which may result from the processes of detoxification, inactivation or compartmentalization of glyphosate (Ahsan et al., 2008) (Figure 1). The increased activity of the 3-deoxy-D-arbino heptulosonate 7-phosphate synthase enzyme (DAHP) and the production of high concentrations of phenolic compounds and aromatic amino acids may allow the resistant biotype's metabolism to remain active for longer than susceptible biotypes (Pline-Srnic, 2006). However, this increased metabolism is reduced at $7 \mathrm{DAH}$ for both biotypes; for the resistant biotype, there is a tendency of maintaining photosynthesis and transpiration until 14 DAH (Figure 1).

Carboxylation efficiency (CE) represents, indirectly, the rubisco activity. The increase of the $\mathrm{CO}_{2}$ concentration inside the leaf induces increases in photosynthetic efficiency, primarily by inhibiting the rubisco enzyme oxygenase activity (ribulose-1, 5-bisphosphate 


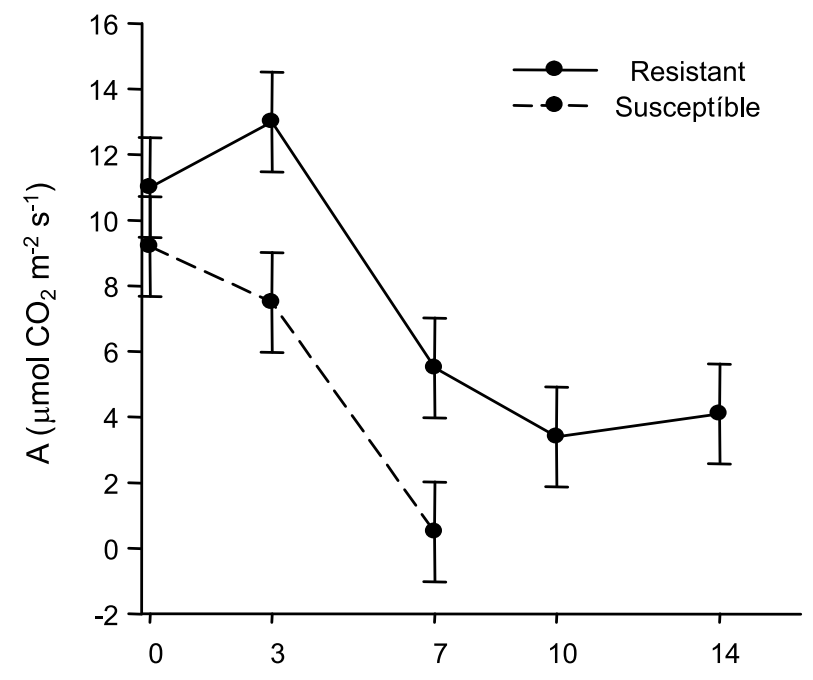

Days after application of the herbicide

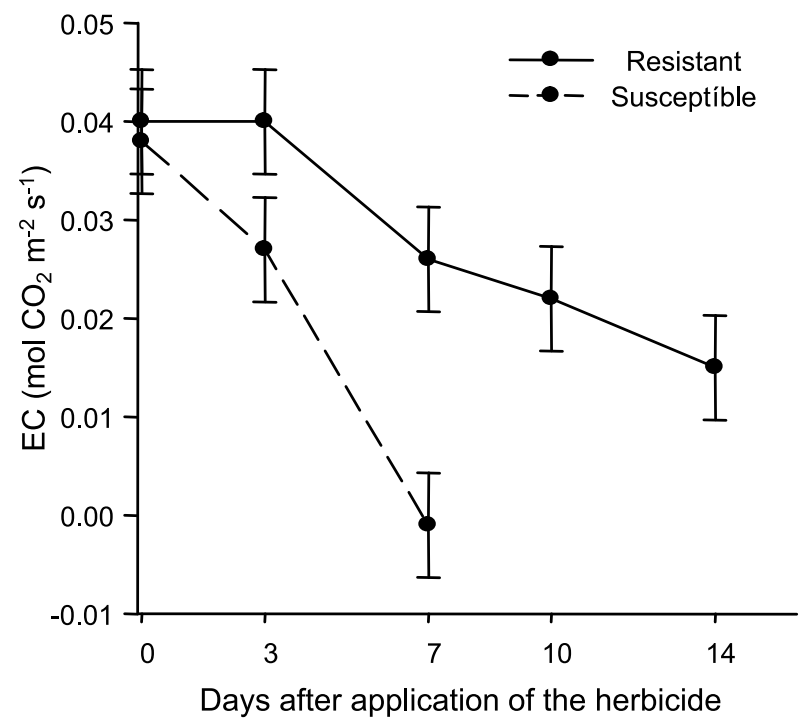

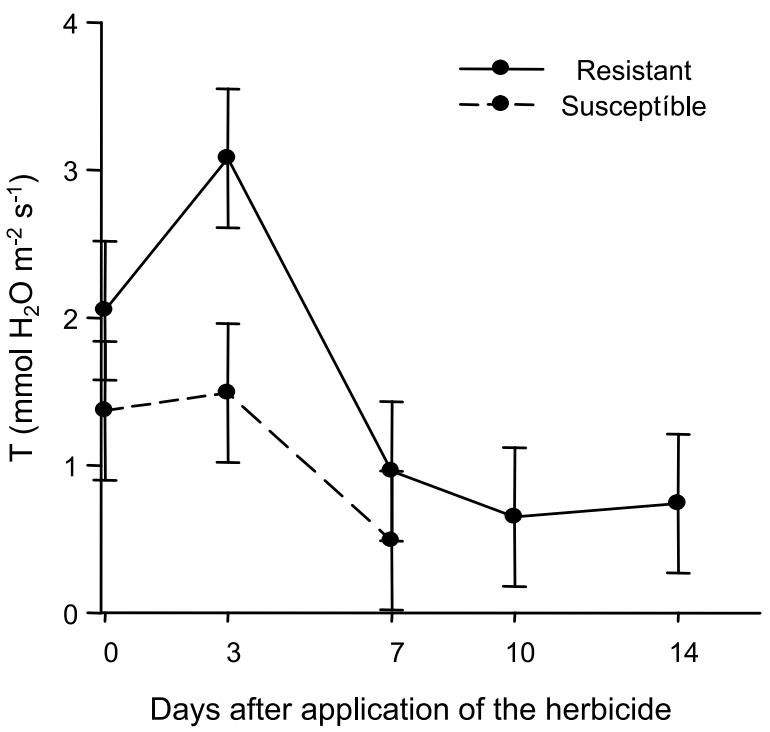

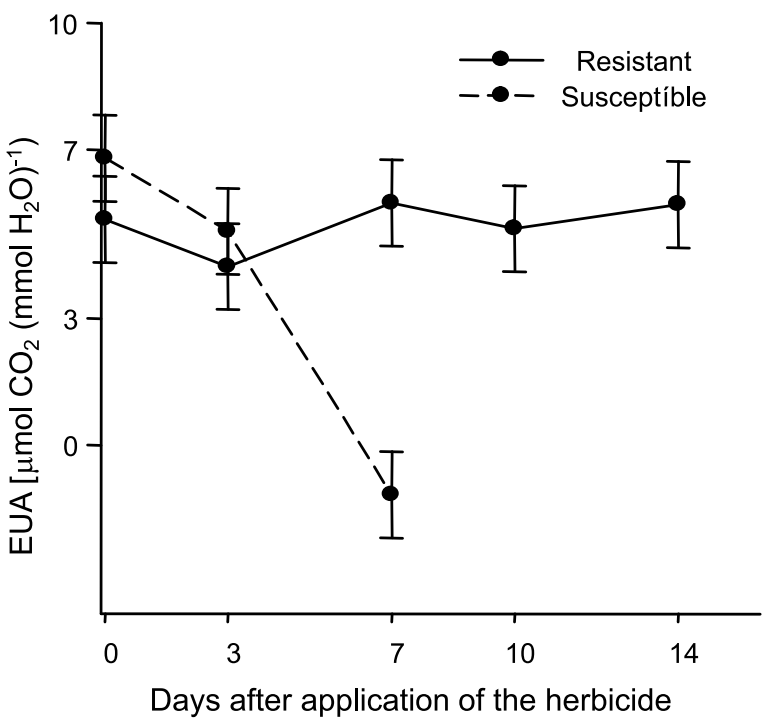

Bars represent least significant difference (LSD) $(\mathrm{p}<0.05)$.

Figure 1 - Photosynthetic rate $(\mathrm{A})\left(\mu \mathrm{mol} \mathrm{CO} \mathrm{Cm}^{-2} \mathrm{~s}^{-1}\right)$, transpiration rate $(\mathrm{T})\left(\mathrm{mmol} \mathrm{H}_{2} \mathrm{O} \mathrm{m}^{-2} \mathrm{~s}^{-1}\right)$, carboxylation efficiency $(\mathrm{CE})$ $\left(\mathrm{mol} \mathrm{CO} \mathrm{m}^{-2} \mathrm{~s}^{-1}\right)$ and water use efficiency (WUE) $\left[\mu \mathrm{mol} \mathrm{CO} \mathrm{CO}_{2}\left(\mathrm{mmol} \mathrm{H}_{2} \mathrm{O}\right)^{-1}\right]$ of resistant and susceptible horseweed biotypes, in function of days after glyphosate application.

carboxylase/oxygenase) (Long et al. 2006). Both biotypes showed a reduction in $\mathrm{CE}$, especially from the third DAH (Figure 1); until $7 \mathrm{DAH}$, the susceptible biotype presented significantly lower $\mathrm{CE}$ compared to the resistant biotype.

No significant change in water use efficiency occurred for the resistant biotype after herbicide application, remaining constant until 14 DAH (Figure 1). On the other hand, the application of glyphosate significantly decreased the response of water use efficiency for the susceptible biotype, with reductions after $7 \mathrm{DAH}$, from which the plant started to limit the assimilation of $\mathrm{CO}_{2}$. The comparison between biotypes showed that up to $3 \mathrm{DAH}$ there was no significant difference in water 


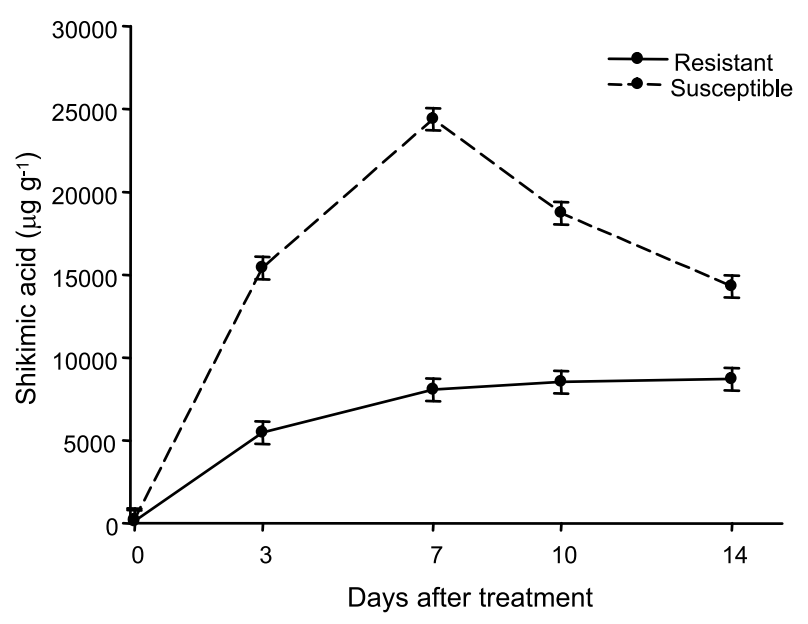

Bars represent least significant difference (LSD) $(\mathrm{p}<0.05)$.

Figure 2 - Accumulation of shikimic acid in horseweed biotypes resistant and susceptible to glyphosate, in function of days after treatment (1,080 $\mathrm{g}$ ha ${ }^{1}$ of e.a.).

use efficiency. At $7 \mathrm{DAH}$, WUE by the resistant biotype was significantly higher than the susceptible biotype. The highest WUE can be explained by stomatal closure and consequent reduction of transpiration, or, according to Reddy et al. (2004), the side effects of glyphosate, such as production of metabolites (AMPA), may contribute to the herbicide action, causing phytotoxic effects affecting photosynthesis, transpiration and WUE (Zobiole et al., 2010b).

The concentration of endogenous shikimic acid did not differ among horseweed biotypes at $0 \mathrm{DAH}$, with average values of 149 and $212 \mu \mathrm{g} \mathrm{g}^{-1}$ for the resistant and susceptible biotypes, respectively (Figure 2), of the same magnitude of those observed by Reddy et al . (2008) for C. canadensis. The endogenous shikimic acid varies according to the species, stage of development and environmental conditions (Matallo et al. 2,009), serving as an indirect parameter to indicate EPSPs inhibition by glyphosate, even if the first metabolite of glyphosate, AMPA, can also cause accumulation of shikimic acid in plants (Reddy et al., 2008).

Figure 3 shows the chromatograms at $3 \mathrm{DAH}$ with the absorption peaks of endogenous shikimic acid, with retention time of 5.6 minutes, referring to the shikimic acid standards (A), and of resistant (blue line) and susceptible (red line) biotypes (B) in response to treatment with glyphosate.

In both horseweed biotypes evaluated there was an increase in the concentration of shikimic acid induced by application of glyphosate (Figure 2). However, the highest concentrations were observed in the susceptible biotype, in all periods, compared to the resistant biotype. The increase in the concentration of shikimic acid in the susceptible biotype was observed until $7 \mathrm{DAH}$, with a peak of approximately $24,000 \mu \mathrm{g} \mathrm{g}^{-1}$, with further decrease in the two subsequent assessments. The shikimic acid concentration at the accumulated peak for the susceptible biotype was approximately 113 times the concentration of the endogenous at 0 DHA.

For the resistant biotype, the shikimic acid concentration also rose until $7 \mathrm{DAH}$, with a concentration 65 times higher than that of the endogenous determined at $0 \mathrm{DAH}$, remaining stable until $14 \mathrm{DAH}$, constituting a partial inhibition of EPSPs (Figure 2). These results are similar to those found in the literature, in which resistant and susceptible biotypes of $C$. canadensis to glyphosate present accumulation of shikimic acid (Mueller et al., 2003; Feng et al. 2004). In Conyza sp. biotypes resistant to glyphosate, whose resistance mechanism is reduced translocation of the herbicide in the plant, was also observed the accumulation of shikimic acid after application of the herbicide (Feng et al. 2004).

The resistance mechanism related to the insensitivity of the EPSPS enzyme to glyphosate is controlled by mutations that alter the amino acid sequence of the enzyme, and changing the amino acid proline in position 106 is the main change which confers insensitivity of this enzyme to the herbicide. Plants that have mutations in the amino acid sequence in EPSPs confer low levels of herbicide resistance, about two to four times (Kaundun et al., 2011), while the resistance to action mechanisms of ACCase, ALS, and photosystem II inhibitors provide levels between 20 and 100 times, compared to the susceptible (Devine \& Shukla, 2000).

Substitutions of the amino acid proline at position 106 of the EPSPs gene for other amino acids can lead to different levels of resistance. 

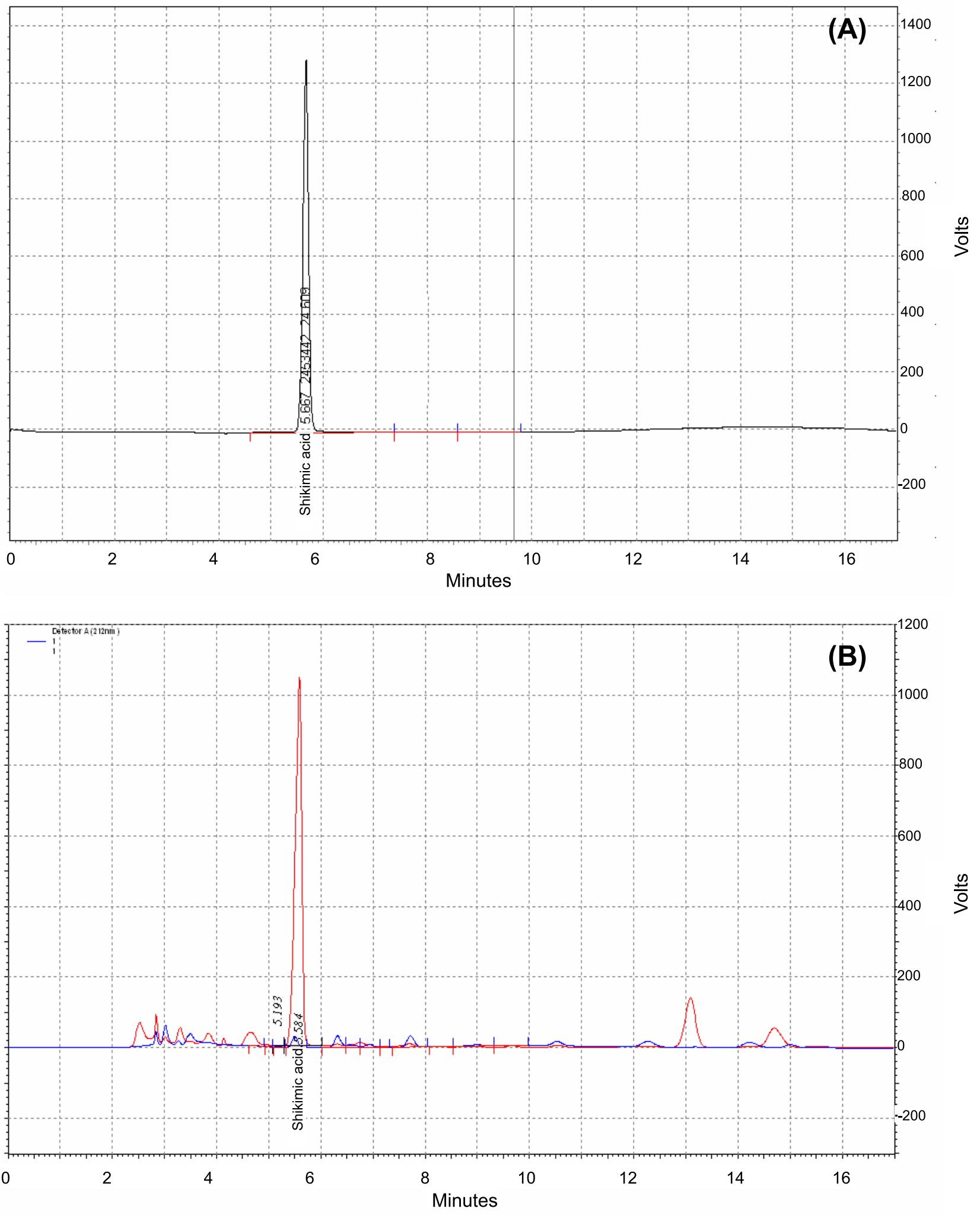

Figure 3 - Chromatogram with standard sample of shikimic acid (A) and (B) chromatogram of the resistant (blue line) and susceptible (red line) biotypes three days after herbicide application. 
In Lolium multiflorum biotypes the substitution of proline for alanine has resistance levels up to 15 times, while substitutions of proline for serine confers resistance levels of up to five times (Jasieniuk et al. 2008). In the Lolium rigidum population, the substitution of proline for threonine confers a resistance level of up to 3.4 times (Wakelin \& Preston, 2006). In Eleusine indica, another species that is resistant to changes in EPSPs, the same substitutions occurring in Lolium multiflorum (proline for alanine) confer low levels of resistance (Kaundun et al. 2008). Still, Carvalho et al. (2012) found two amino acid substitutions at positions 182 and 310 of the EPSPS gene that may contribute to resistance to glyphosate, changing proline for threonine and tyrosine for cysteine, respectively.

Possibly other mechanisms of resistance may be associated with this resistant biotype, such as the reduction in glyphosate translocation, as observed for C. bonariensis (Ferreira et al. 2008) and C. canadensis (Feng et al. 2004). Thus, the results of this study indicate that the application of glyphosate adversely affects photosynthetic parameters of the susceptible biotype, and the accumulation of shikimic acid, in the resistant biotype, indicates that the mechanism of resistance is not only related to the insensitivity of EPSPs to glyphosate and/or other resistance mechanisms may be involved.

\section{LITERATURE CITED}

AHSAN, N. et al. Glyphosate-induced oxidative stress in rice leaves revealed by proteomic approach. Plant Physiol

Biochem., v. 46, n. 12, p. 1062-1070, 2008.

CARVALHO, L. B. et al. Pool of resistance mechanisms to glyphosate in Digitaria insularis. J. Agric. Food Chem., v. 60, n. 2, p. 615-622, 2012.

DEVINE, D.; SHUKLA, A. Altered target site as a mechanism of herbicide resistance. Crop Protec., v. 19, n. 8-10, p. 881-889, 2000.

DUKE, S. O.; BAERSON, S. R.; RIMANDO, A. M. Glyphosate. New York: Wiley. 2003. 120 p.

FENG, P. C. C. et al. Investigations into glyphosate-resistant horseweed (Conyza canadensis): retention, uptake, translocation, and metabolism. Weed Sci., v. 52, n. 4, p. 498-505, 2004.

Planta Daninha, Viçosa-MG, v. 32, n. 1, p. 151-159, 2014
FERREIRA, E. A. et al. Glyphosate translocation in hairy fleabane (Conyza bonariensis) biotypes. Planta Daninha, v. 26, n. 3, p. 637-643, 2008.

GEIGER, D. R.; SHIEH, W. J.; FUCHS, M. A. Causes of selflimited translocation of glyphosate in Beta vulgaris plants. Pest. Biochem. Physiol., v. 64, n. 2, p. 124-133, 1999

HEAP, I. M. International survey of herbicide resistant weeds. Disponível em: <http://www.weedscience.com>. Acesso em: 26 jul. 2012.

HERRMANN, K. M. The shikimate pathway: early steps in the biosynthesis of aromatic compounds. Plant Cell., v. 7, n. 7, p. 907-919, 1995a.

HERRMANN, K. M. The shikimate pathway as an entry to aromatic secondary metabolism. Plant Physiol., v. 107, n. 1, p. 7-12, 1995b.

HOLLANDER-CZYTKO, H.; AMRHEIN, N. Subcellular compartmentation of shikimic acid and phenylalanine in buckwheat cell-suspension cultures grown in the presence of shikimate pathway inhibitors. Plant Sci. Lett., v. 29, n. 1, p. 89-96, 1983.

JASIENIUK, M. et al. Glyphosate-resistant Italian ryegrass (Lolium multiflorum) in California: distribution, response to glyphosate, and molecular evidence form an altered target enzyme. Weed Sci., v. 56, n. 4, p. 496-502, 2008.

KAUNDUN, S. S. et al. Importance of the P106S target-site mutation in conferring resistance to glyphosate in a goosegrass (Eleusine indica) population from Philippines. Weed Sci., v. 56, n. 5, p. 37-646, 2008.

KAUNDUN, S. S. et al. A novel P106L mutation in EPSPS and an unknown mechanism(s) act additively to confer resistance to glyphosate in a South African Lolium rigidum population. J. Agric. Food Chem., v. 59, n. 7, p. 3227-3233, 2011.

LONG, S. P. et al. Can improvement in photosynthesis increase crop yields? Plant Cell Environ., v. 29, n. 3, p. 315-330, 2006.

MATALLO, M. B. et al. Microwave-assisted solvent extraction and analysis of shikimic acid from plant tissues. Planta Daninha, v. 27, p. 987-994, 2009. (Número Especial)

MUELLER, T. C. et al. Shikimate accumulates in both glyphosate-sensitive and glyphosate-resistant horseweed (Conyza canadensis L. Cronq.). J. Agric. Food Chem., v. 51, n. 3, p. 680-684, 2003.

NANDULA, V. K. et al. Glyphosate-resistant and susceptible soybean (Glycine max) and canola (Brassica napus) dose response and metabolism relationships with glyphosate. J. Agric. Food Chem., v. 55, n. 9, p. 3540-3545, 2007. 
PLINE-SRNIC, W. Physiological mechanisms of glyphosate resistance. Weed Technol., v. 20, n. 2, p. 290-300, 2006.

REDDY, K. N.; RIMANDO, A. M.; DUKE, S. O. Aminomethylphosphonic acid, a metabolite of glyphosate, causes injury in glyphosate-treated, glyphosate-resistant soybean. J. Agric. Food Chem., v. 52, n. 16, p. 5139-5143, 2004.

REDDY, K. N. et al. Amino methyl phosphonic acid accumulation in plant species treated with glyphosate. J. Agric. Food Chem., v. 56, n. 6, p. 2125-2130, 2008.

SERGIEV, I. G. et al. The phenylurea cytokinin 4PU-30 protects maize plants against glyphosate action. Pest. Biochem. Physiol., v. 85, n. 3, p. 139-146, 2006.
WAKELIN, A. M.; PRESTON, C. A target site mutation is present in a glyphosate-resistant Lolium rigidum population. Weed Res., v. 46, n. 5, p. 432-440, 2006.

ZELAYA, I. A. et al. Evalution os spectriphotometric and HPLC methods for shikimic acid determination on plants: models in glyphosate-resistant and susceptible crops. J. Agric. Food Chem., v. 59, n. 6, p. 2202-2212, 2011.

ZOBIOLE, L. H. S. et al. Water use efûciency and photosynthesis of glyphosate-resistant soybean as affected by glyphosate. Pest. Biochem. Physiol., v. 97, n. 3, p. 182-193, 2010a.

ZOBIOLE, L. H. S. et al. Nutrient accumulation and photosynthesis in glyphosate-resistant soybeans is reduced under glyphosate use. J. Plant Nutr., v. 33, n. 12, p. 1860-1873, 2010b. 